\title{
Catalysis of Henry Reaction by Plasmid DNA
}

Xiangjun $\mathrm{Di}^{1} \uparrow$, Xiaowen Zhang ${ }^{1} \uparrow$, Yingwu Wang ${ }^{1 *}$, Yan Wang ${ }^{2}$, Chunguang Lai ${ }^{1}$, Xiaoqiang

$$
\mathrm{Wu}^{3} \text {, Ping Liu }{ }^{3} \text {, Shuang } \mathrm{Liu}^{3} \text {, Renjun } \mathrm{Gao}^{1 *}
$$

1 School of Life Science, Key Laboratory for Molecular Enzymology and Engineering, the Ministry of Education, Jilin University, Changchun 130012, China

2 School of Applied Chemistry and Biotechnology, ShenZhen Polytechnic, China

3 GeneScience Pharmaceuticals Co., Ltd. (GenSci), Changchun 130012, China

$\dagger$ Co first author

* Correspondence: Renjun Gao gaorj@jlu.edu.cn; Tel.: +86-18604313058

Yingwu Wang wyw@jlu.edu.cn; Tel.: +86-13844072416

\begin{abstract}
This work demonstrates that a plasmid can function as an efficient biocatalyst in mediating the nitroaldol (Henry) reaction at high temperatures in ultrapure water. Compared with ssDNA, the plasmid displayed a remarkable catalytic efficiency $(97 \%$ yield within $20 \mathrm{~min}$ ). Aromatic aldehydes which bear strong or moderate electronwithdrawing groups reacted satisfactorily with nitromethane, which afforded the corresponding $\beta$-nitroalcohols in good yields within $2 \mathrm{~h}$ (up to 98\%). By contrast, aliphatic and aromatic aldehydes with electron-donating groups did not react. Moreover, the yield significantly dropped when the size of the carbanion increased, and the yield was only $10 \%$ when nitropropane was used as the donor.
\end{abstract}

Keywords: ssDNA; plasmid; pcDNA3.1; Henry Reaction; C-C bond formation 


\section{Introduction}

Since the 3D structure of the DNA double helix has been discovered by Watson and Crick in 1953[1], the double-helix structure with base pairs has attracted considerable attention as an effective means of storing and transferring genetic information[2]. With the development of science and technology, the study of the DNA double-helix structure has expanded from biology to other science domains [3-7]. Recently, the interest in DNA has focused on the catalysis of organic synthesis[8-10]. Till now, DNA catalysts have four types, namely, ssDNA[11], human telomeric G-quadruplex DNA[12], ctDNA[11] and oligonucleotide[13]. The application of DNA-based hybrid catalysts in asymmetric catalysis in the form of a copper(II)-catalysed Diels-Alder reaction was first reported by Feringa and Roelfes in 2005[14]. Since then, DNA catalysts have become extensively used in the Henry reaction[15], Michael additions[16] and so on.

The Henry reaction is important in forming C-C bonds[17] which are needed in synthesising important compounds[18]. This reaction is usually catalysed by chiral guanidine, chiral (thio) urea derivatives and cinchona alkaloids, but the solvents are mostly organic, which are considerably harmful to the environment. Therefore, the use of environmental-friendly alternatives to these harmful substances is important.

ssDNA has used as a catalyst in the Henry reaction[11]. However, the application of ssDNA has many limitations. For example, consistency in the size and sequence of ssDNAs cannot be guaranteed. Different from ssDNAs, plasmids are stable and can be amplified from generation to generation without mutations. Thus, we attempted to use plasmid DNA to catalyse the Henry reaction. This paper not only presents the capability of plasmid DNA to catalyse the Henry reaction with high yield but also provides a new option for DNA-based catalysis. We demonstrated that plasmid DNA can also be a biomolecular scaffold for chiral transfer and cause an additional rate acceleration.

\section{Results and Discussion}

The catalytic effect of DNA from different sources (lab-extracted and commercial products) was primarily evaluated (Table 1). The highest yield was 55\%, which was achieved when plasmids (pET32a and pcDNA3.1) were used as catalysts for the nitroaldol condensation of 4-nitrobenzaldehyde and 
nitromethane (Table 1, entries 4 and 5). By contrast, the commercial ssDNA (deoxyribonucleic acid sodium salt from salmon tests) afforded low yields[11] (only $34 \%$ ) under $37{ }^{\circ} \mathrm{C}$ within $2 \mathrm{~h}$ (Table 1 , entry 1). No significant difference was observed among the four types of plasmids, which were 50\%, 53\%, and 55\% (Table 1, entries 2, 3, 4 and 5). Consequently, plasmid pcDNA3.1 was chosen as a representative in subsequent studies because it can be replicated easily. In consideration that DNA possesses a right-handed helix structure, the chiral information within the DNA may transfer to the organic reaction products[15]. Therefore, we also tested the ee value of the DNA-mediated Henry reaction. However, no enantioselectivity was observed, indicating that the DNA catalyst did not provide chiral selectivity under this condition.

Table 1 Catalytic effect of different DNA for Henry reactions ${ }^{\mathrm{a}}$

\begin{tabular}{cccccc}
\hline Entry & DNA & & Temperature & Time & Yieldb \\
\hline 1 & ssDNA & & $37^{\circ} \mathrm{C}$ & $2 \mathrm{~h}$ & $34 \%$ \\
2 & pUC18 & E.coli DH5 $\alpha$ & $37^{\circ} \mathrm{C}$ & $2 \mathrm{~h}$ & $50 \%$ \\
3 & pET20b & E.coli DH5 $\alpha$ & $37^{\circ} \mathrm{C}$ & $2 \mathrm{~h}$ & $53 \%$ \\
4 & pET32a & E.coli DH5 $\alpha$ & $37^{\circ} \mathrm{C}$ & $2 \mathrm{~h}$ & $55 \%$ \\
5 & pcDNA3.1 & E.coli DH5 $\alpha$ & $37^{\circ} \mathrm{C}$ & $2 \mathrm{~h}$ & $55 \%$ \\
\hline
\end{tabular}

a Reaction conditions: 4-nitrobenzaldehyde (0.1 mM), nitromethane (2.5 mM), pure water (2 mL), $0.3 \mathrm{mg}$ DNA, $37^{\circ} \mathrm{C}, 2$ h. ${ }^{\mathrm{b}}$ The yields were determined by HPLC using a Chiralpak AD-H chiral column.

\subsection{Influence of the mole ratio of nitromethane to 4-nitrobenzaldehyde}

The Henry reaction is a nucleophilic addition reaction, and nitromethane is a nucleophile which can react with the carbonyl of 4-nitrobenzaldehyde. Therefore, an excessive dosage of nitromethane favours the shift of the reaction equilibrium to the formation of products[18]. Fig. 1 demonstrates that the yields of Henry reaction increase from $1.2 \%$ to $98 \%$ with the growth of the molar ratio of nitromethane to 4 nitrobenzaldehyde from $1 / 1$ to $25 / 1$. This result is consistent with the reported procedures which typically require an excess of approximately 25 -fold mole to perform the biocatalytic Henry reaction and obtain high yields[19]. Thus, we selected 25 equiv. of nitromethane as the optimum molar equivalent for the Henry reaction. 


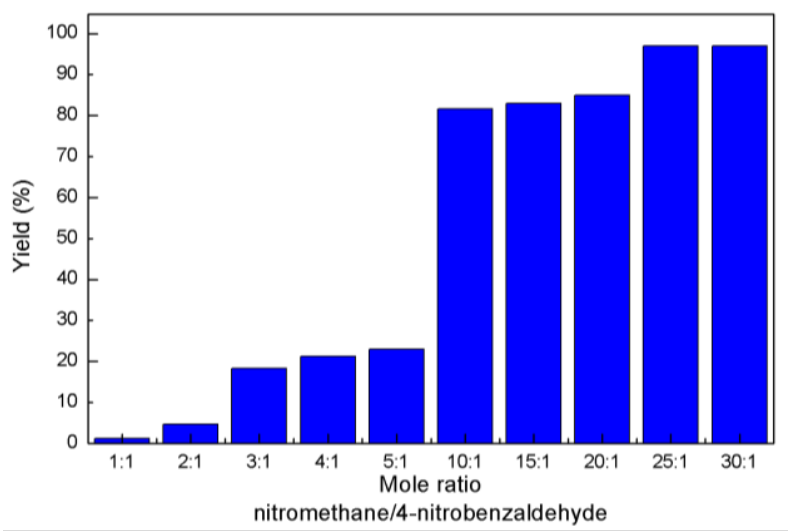

Fig. 1. The effect of mole ratio of nitromethane to 4-nitrobenzaldehyde on the reaction. The Henry reaction was carried out at $70{ }^{\circ} \mathrm{C}$ for $2 \mathrm{~h}$ using $0.1 \mathrm{mM}$ 4-nitrobenzaldehyde, $0.3 \mathrm{mg}$ of pcDNA3.1.

\subsection{Effect of temperature on catalytic efficiency}

According to Arrhenius theory, temperature can increase the internal energy of the substrate molecules to overcome the energy barrier and thus enhance the reaction rate and enzyme kinetics[20]. Therefore, the catalytic efficiency of the Henry reaction was evaluated at different temperatures from $20{ }^{\circ} \mathrm{C}$ to $80{ }^{\circ} \mathrm{C}$ (Fig. 2). As shown in Fig. 2, the yields of pcDNA3.1 increased with temperature. After peaking at $70{ }^{\circ} \mathrm{C}(98 \%)$, the yields dropped slightly. The rising trend was also observed in the yields of ssDNA. Unfortunately, the best catalytic performance of ssDNA in the Henry reaction was only $67 \%$, which was considerably below that of pcDNA3.1.

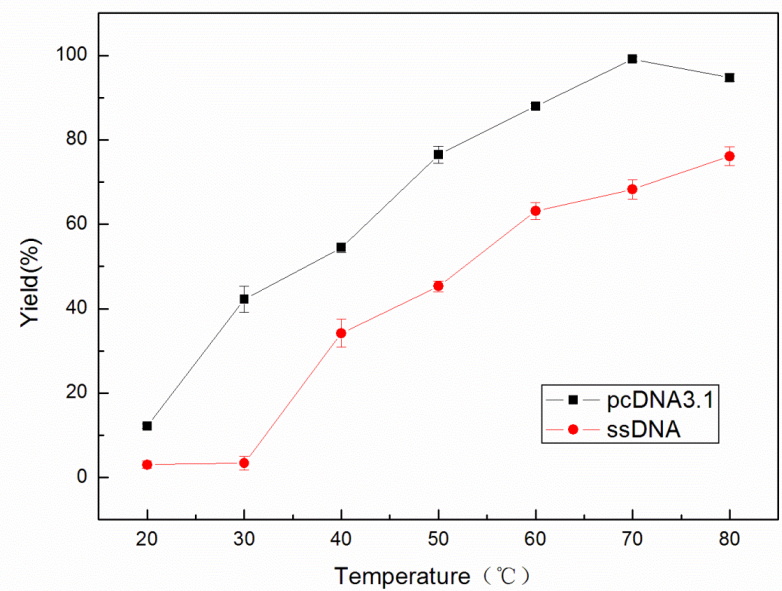

Fig. 2. The effect of temperature on the yields in the Henry reaction catalyzed by pcDNA3.1 and ssDNA. The Henry reaction was carried out at different tenperature for $2 \mathrm{~h}$ using 0.1 $\mathrm{mM}$ 4-nitrobenzaldehyde, $2.5 \mathrm{mM}$ nitromethane and $0.3 \mathrm{mg}$ DNA

\subsection{Effect of reaction time on yields}

We optimised the reaction time using the following coupling conditions: $0.1 \mathrm{mM}$ 4- 
nitrobenzaldehyde, $2.5 \mathrm{mM}$ nitromethane, $70{ }^{\circ} \mathrm{C}, 0.3 \mathrm{mg}$ DNA for pcDNA3.1 and ssDNA. The results are shown in Fig. 3. The catalytic efficiency of pcDNA3.1 was markedly higher than that of ssDNA. For example, during the first 20 min, pcDNA3.1 yielded four times more $\beta$-nitroalcohol than when the reaction was run for the same amount of time using ssDNA as the biocatalyst, and the yields of the Henry reaction catalysed by pcDNA3.1 remained stable until the end. Although the reaction that was catalysed by ssDNA exhibited a steady increase to $67 \%$ after $2 \mathrm{~h}$, the figure was still less than that of pcDNA3.1 (98\%). Currently reported enzymes which catalyse Henry reaction with high efficiencies of $65 \%$ and $75 \%$ after $30 \mathrm{~min}$ are pancreatic lipase HPL and MJL, respectively[20-22]. However, pcDNA3.1 demonstrated a remarkably higher efficiency than HPL and MJL in catalysing the Henry reaction.

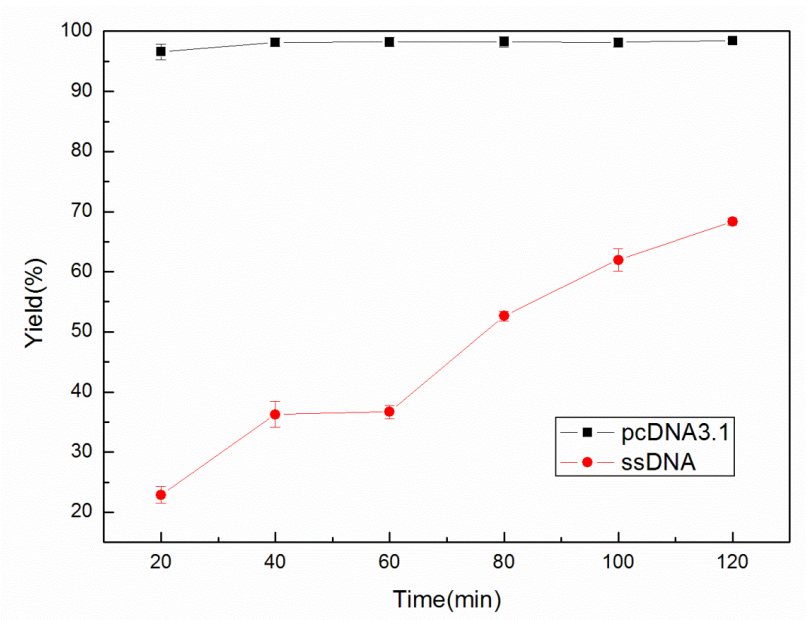

Fig. 3. Time course of yields in the Henry reaction catalyzed by pcDNA3.1 and ssDNA. The Henry reaction was carried out at $70^{\circ} \mathrm{C}$ for $2 \mathrm{~h}$ using $0.1 \mathrm{mM}$ 4-nitrobenzaldehyde, $2.5 \mathrm{mM}$ nitromethane and $0.3 \mathrm{mg}$ DNA.

\subsection{Effect of recycling times on yields}

We also investigated the recycling of the catalytic DNA. Fig. 4 depicts the efficiency of the same catalyst used 10 times in the reaction of 4-nitrobenzaldehyde and nitromethane under optimised reaction conditions. Even after the 10th round, no reduction in reaction yield was observed. 


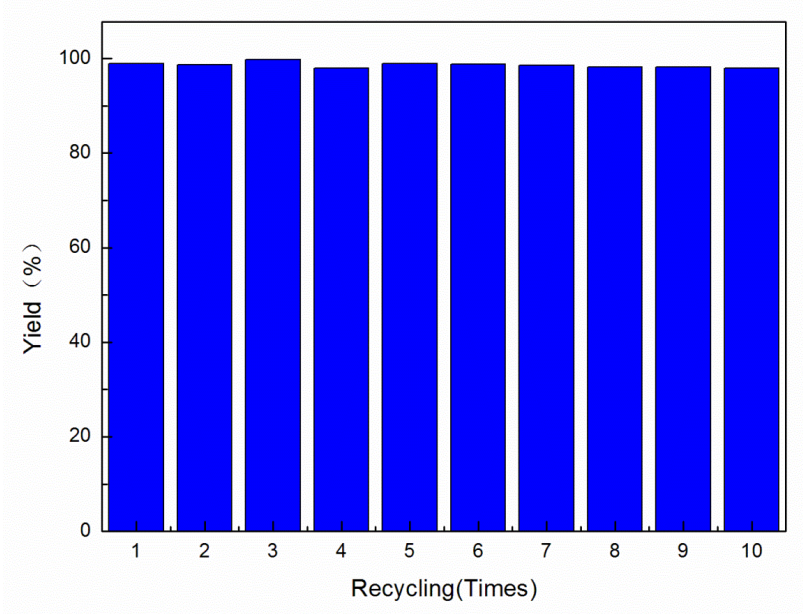

Fig. 4. Effect of recycling times on yields. The Henry reaction was carried out at $70^{\circ} \mathrm{C}$ for 2 h using 0.1 mM 4-nitrobenzaldehyde, $2.5 \mathrm{mM}$ nitromethane and $0.3 \mathrm{mg}$ DNA.

\subsection{Effect of substrates with different substituents on pcDNA3.1-catalysed Henry reaction}

Different benzaldehydes with electron-donating or electron-withdrawing substituents were tested under optimised conditions (Table 2). Benzaldehydes with strong or moderate electron-withdrawing substituents can react with nitromethane satisfactorily and result in $\beta$-nitroalcohols in good yields within $2 \mathrm{~h}$ (Table 2, entries 1, 2, 3 and 4). The position of nitro-substituents also influences the yields of the pcDNA3.1-catalysed Henry reaction. p-Nitrobenzaldehyde reacted more easily with nitromethane than o-nitrobenzaldehyde and m-nitrobenzaldehyde (Table 2, entries 1, 2 and 3). However, aliphatic aldehydes (e.g. benzaldehyde) and aromatic aldehydes which bear electron-rich groups (e.g. 4methoxybenzaldehyde and 4-hydroxybenzaldehyde) remained unreacted under these conditions.

Table 2 pcDNA3.1-catalyzed Henry reaction of substituted aldehydes with nitromethane ${ }^{\mathrm{a}}$

\begin{tabular}{llll} 
& & & \\
\hline
\end{tabular}


a The Henry reaction was carried out at $70^{\circ} \mathrm{C}$ for $2 \mathrm{~h}$ using $0.1 \mathrm{mM}$ benzaldehydes, $2.5 \mathrm{mM}$ nitromethane and $0.3 \mathrm{mg}$ DNA.

Meanwhile, we found that the yields dropped significantly as the numbers of the carbon atoms of nitroalkanes increased, with $44 \%$ for nitroethane (Table 3, entry 2 ) and only $10 \%$ for nitropropane (Table 3, entry 3). This phenomenon may be attributed to two reasons. First is water solubility. Nitromethane is partially soluble in water, whereas nitroethane and nitropropane are nearly insoluble in water. The lower the solubility, the lower the chance of having contact with the catalyst. The other reason is steric hindrance[23]. The steric hindrance is large with nitropropane; thus, the reaction with 4-nitrobenzaldehyde is difficult.

Table 3 pcDNA3.1-catalyzed Henry reaction of different nitroalkanes with 4nitrobenzaldehyde $^{\mathrm{a}}$

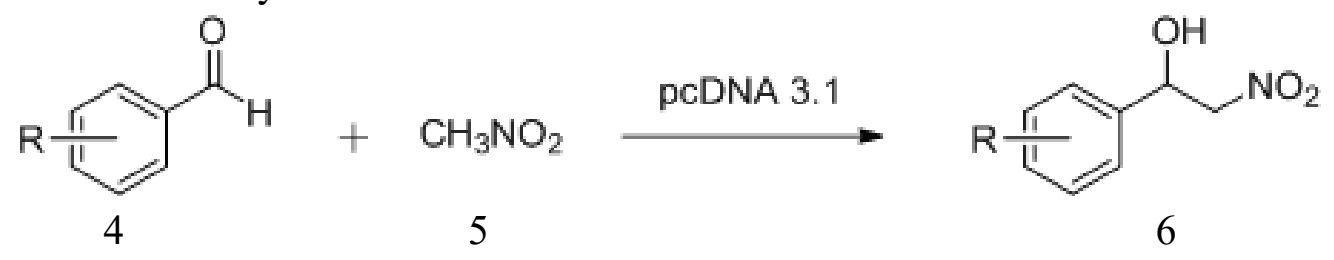

\begin{tabular}{llll}
\hline Entry & 4 & $\mathrm{R}(5)$ & Yields \\
\hline 1 & 4-nitrobenzaldehyde & nitromethane & $98 \%$ \\
2 & 4-nitrobenzaldehyde & nitroethane & $44 \%$ \\
3 & 4-nitrobenzaldehyde & nitropropane & $10 \%$ \\
\hline
\end{tabular}

${ }^{a}$ The Henry reaction was carried out at $70^{\circ} \mathrm{C}$ for $2 \mathrm{~h}$ using $0.1 \mathrm{mM}$ 4-nitrobenzaldehyde, $2.5 \mathrm{mM}$ nitroalkanes and $0.3 \mathrm{mg}$ DNA.

\section{Experimental Section}

\subsection{Materials}

Adenine (CAS 73-24-5) was purchased from Sangon Biotech. Aldehydes were supplied by Sangon Biotech. Nitroalkanes were purchased from Sinopharm Chemical Reagent Co., Ltd. (Shanghai, China). Plasmid DNA maxiprep kits were purchased from Thermo Fisher Scientific. Silica gel plates were supplied by Branch of Qingdao Haiyang Chemical Co., Ltd. (Qingdao, China). Milli-Q water was used for the experiments in aqueous solutions. Deoxyribonucleic acid sodium salt from salmon sperms (CAS 438545-06-3; Cat. No. D1626) was supplied by Sigma-Aldrich. All reagents and solvents were purchased from Beijing Dingguo Changsheng Biotechnology Co., Ltd. (Beijing, China). Plasmids 
pUC18, pET-20b, pET-32a and pcDNA3.1 were conserved in the laboratory. Escherichia coli strain DH5 $\alpha$ was used for DNA manipulation and amplification.

\subsection{Methods}

The plasmid was amplified in the host $E$. coli DH5 $\alpha$. The cell was cultured in 2 YT medium (1\% yeast extract, $1.6 \%$ tryptone and $0.5 \% \mathrm{NaCl}$ ) containing $100 \mu \mathrm{g} / \mathrm{mL}$ ampicillin at $37{ }^{\circ} \mathrm{C}$ overnight. The cells were collected by centrifugation at $8000 \mathrm{r} / \mathrm{min}$ for $15 \mathrm{~min}\left(4{ }^{\circ} \mathrm{C}\right)$ and then stored at $-20{ }^{\circ} \mathrm{C}$. The cells were extracted using the ZymoPURE Plasmid Maxiprep Kit. The obtained DNA was stored at $-40{ }^{\circ} \mathrm{C}$.

${ }^{1} \mathrm{H}-\mathrm{NMR}$ spectra were recorded on an AvanceIII600 spectrometer (Bruker) or a Mercury 300BB spectrometer (Varian) using $\mathrm{CDCl}_{3}$ as a solvent. MS spectra were obtained by a AB Sciex Triple TOF 6600. Relative configurations of the compounds were assigned by comparison with 1H-NMR data reported in the literature. HPLC analysis was carried on a Waters e2695 equipped with a UV detector and a Chiralpak AD-H chiral column to determine the yield and the potential enantioselectivity. HPLC analysis was performed using $90 \%$ of $n$-hexane and $10 \%$ of isopropanol as eluents. The flow rate was 1 $\mathrm{mL} / \mathrm{min}$, and the run time was $60 \mathrm{~min}$.

\subsection{General procedure for DNA-catalyzed Henry reactions}

In a glass bottle, $0.3 \mathrm{mg}$ of DNA, $2 \mathrm{~mL}$ of ultrapure water containing 4-nitrobenzaldehyde $(0.1 \mathrm{mM}$, $15.1 \mathrm{mg})$ and nitromethane $(2.5 \mathrm{mmol}, 134 \mu \mathrm{L})$ were mixed. The reaction mixture was gently stirred (200 rpm) at $70{ }^{\circ} \mathrm{C}$ for $1 \mathrm{~h}$. After completion, $1 \mathrm{~mL}$ of water was added. The reaction mixture was washed with EtOAc three times and then dried at $0.1 \mathrm{mbar}$ and $30^{\circ} \mathrm{C}$. The resulting products were purified using column chromatography and petroleum ether/ethyl acetate $(5: 2 \mathrm{v} / \mathrm{v})$ as the eluent. To determine the NMR yield, the obtained product was dissolved in $\mathrm{CDCl} 3$. The reaction progress was monitored by thin-layer chromatography and HPLC analysis.

The spectral data of the compound matched those reported in the literature.

\subsection{Typical Recycling Procedure}

After the reaction, the aqueous phase was washed with EtOAc three times in the reaction vial. The 
organic phase was removed, and the vial with the aqueous phase was subjected to $\mathrm{N}_{2}$-flow before adding the reaction substrates for the next run.

\section{Conclusions}

For the first time, the plasmid was used as DNA catalyst for henry reaction. It turns out that, a superior activity (97\% yields and 20 mins) could be achieved compared to ssDNA ( $21 \%$ yields within 20 mins) at the temperature of $70^{\circ} \mathrm{C}$. Overall, this research not only presents the unmodified plasmid DNA can catalyze Henry reaction with high yield, but also provides a new option for DNA-based catalysis. It demonstrated that plasmid DNA can also be a biomolecular scaffold final rate acceleration.

\section{Acknowledgments}

The acknowledgements come at the end of an article after the conclusions and before the notes and references.

\section{Author Contributions:}

Renjun Gao and Yingwu Wang designed the work. Xiangjun Di, Xiaowen Zhang, Yan Wang, Chunguang Lai, Xiaoqiang $\mathrm{Wu}$ and Ping Liu performed the experiments. Xiangjun Di and Xiaowen Zhang wrote the paper. All authors took part in data analysis and discussion.

\section{Funding:}

The authors are gratefully to the National Natural Science Foundation of China (No. 21778021) for financial support.

Conflicts of Interest: The authors declare no conflict of interest.

\section{References}

1. Watson, J.D.; Crick, F.H. A structure for deoxyribose nucleic acid. Nature 1953, 171, 737-738, DOI. 10.1038/171737a0 Available online: https://doi.org/10.1038/171737a0 (accessed on 14 April 2016).

2. Park, S.; Sugiyama, H. DNA-Based Hybrid Catalysts for Asymmetric Organic Synthesis. Angew. Chem. Int. Ed. Engl. 2010, 49, 3870-3878, DOI. 10.1002/anie.200905382 Available online: https://doi.org/10.1002/anie.200905382 (accessed on 14 April 2016).

3. Ono, A. DNA-synthetic polymer conjugates. Macromol. Chem. Phys. 2006, 207, 1629-1632, DOI. 10.1002/macp.200600370 Available online: https://doi.org/10.1002/macp. 20 0600370 (accessed on 14 April 2016).

4. Endo, M.; Sugiyama, H. Chemical approaches to DNA nanotechnology. ChemBioChem. 2009, 10, 2420-244, DOI. 10.1002/c bic.200900286: Available online: https://doi.org/10.1002/cbic. 
200900286 (accessed on 14 April 2016).

5. Seeman, N.C. Nucleic acid nanostructures and topology. Angew. Chem. Int. Ed. Engl. 1998, 37, 3220-3238, DOI. 10.1002/(SICI) 1521-3773(19981217)37:23<3220::AID-ANIE 3220>3.0.CO;2-C Available online https://doi.org/10.1002/(SICI)1521-3773 (1998 1217)37:23<3220::AID-ANIE3220>3.0.CO;2-C (accessed on 14 April 2016).

6. Seeman, N.C. DNA in a material world. Nature 2003, 421, 427-431, DOI. 10.1038/nature01406 Available online https://doi.org/10.1038/nature01406 (accessed on 14 April 2016).

7. Niemeyer, C.M. Nanoparticles, Proteins, and Nucleic Acids: Biotechnology Meets Materials Science. Angew. Chem. Int. Ed. Engl. 2001, 40, 4128-4158, DOI. 10.1002/15213773(20011119)40:22<4128::AID-ANIE4128>3.0.CO;2-S Available online: https://doi.org/ 10.1002/1521-3773(20011119)40:22<4128::AID-ANIE4128>3.0.CO;2-S (accessed on 02 September 2015).

8. Silverman, S.K. DNA as a versatile chemical component for catalysis, encoding, and stereocontrol. Angew. Chem. Int. Ed. 2010, 49, 7180-7201, DOI. 10.1002/anie.200906345 Available online: https://doi.org/10.1002/anie.200906345 (accessed on 02 September 2015).

9. Silverman, S.K. Deoxyribozymes: Selection design and serendipity in the development of DNA catalysts. Acc. Chem. Res. 2009, 42, 1521-1531, DOI. 10.1021/ar900052y Available online: https://doi.org/10.1021/ar900052y (accessed on 02 September 2015).

10. Jaschke, A.; Seelig, B. Evolution of DNA and RNA as catalysts for chemical reactions. Curr. Opin. Chem. Biol. 2000, 4, 257-262, DOI. 10.1016/S1367-5931(00)00086-7 Available online: https://doi.org/10.1016/S1367-5931(00)00086-7 (accessed on 02 December 2015).

11. Haring, M.; Perez-Madrigal, M.M.; Kuhbeck, D.; Pettignano, A.; Quignard, F.; Diaz, D.D. DNACatalyzed Henry Reaction in Pure Water and the Striking Influence of Organic Buffer Systems. Molecules 2015, 20, 4136-4147, DOI. 10.3390/molecules20034136 Available online: https://doi.org/10.3390/molecules20034136 (accessed on 25 November 2015).

12. Li, Y.; Wang, C.; Hao, J.; Cheng, M.; Jia, G.; Li, C. Higher-order human telomeric G-quadruplex DNA metalloenzyme catalyzed Diels-Alder reaction: an unexpected inversion of enantioselectivity modulated by $\mathrm{K}^{+}$and $\mathrm{NH}^{+}$ions. Chem. Commun. 2015, 51, 13174-13177, DOI. 10.1039/C5CC05215G Available online: https://doi.org/10.1039/C5CC05215G (accessed on 24 March 2017).

13. Mohan, U.; Burai, R.; McNaughton, B.R. In vitro evolution of a Friedel-Crafts deoxyribozyme. Org. Biomol. Chem. 2013, 11, 2241-2244. DOI. 10.1039/C3OB40080H Available online: https://doi.org/10.1039/C3OB40080H (accessed on 01 September 2016).

14. Roelfes, G.; Feringa, B.L. DNA-based asymmetric catalysis. Angew. Chem. Int. Ed. 2005, 44, 3230-3232. DOI. 10.1002/anie.200500298 Available online: https://doi.org/10.1002/anie. 200500298 (accessed on 14 April 2016).

15. Fan, J.; Sun, G.; Wan, C.; Wang, Z.; Li, Y. Investigation of DNA as a catalyst for Henry reaction in water. Chem. Commun. 2008, 0, 3792-3794, ODI. 10.1039/B805767B Available online: https://doi.org/10.1039/B805767B (accessed on 14 April 2016).

16. Dey, S.; Jaschke, A. Tuning the Stereoselectivity of a DNA - Catalyzed Michael Addition through Covalent Modification. Angew. Chem. Int. Ed. Engl. 2015, 54, 11279-11282, DOI:10.1002/anie.201503838 Available online: https://doi.org/10.1002/anie.201503838 (accessed on 23 May 2017).

17. Ma, J.A.; Recent Developments in the Catalytic Asymmetric Synthesis of $\alpha$ - and $\beta$ - Amino Acids. 
Angew. Chem. Int. Ed. Engl. 2003, 42, 4290-4299, ODI. 10.1002/ anie.200301600 Available online: https://doi.org/10.1002/anie.200301600 (accessed on 14 April 2016).

18. Yu, X.; Pérez, B.; Zhang, Z.; Gao, R.; Guo, Z. Mining catalytic promiscuity from Thermophilic archaea: an acyl-peptide releasing enzyme from Sulfolobus tokodaii (ST0779) for nitroaldol reactions. Green Chemistry 2016, 18, 2753-2761, DOI: 10.1039/C5GC02674A Available online: https://doi.org/10.1039/C5GC02674A (accessed on 23 May 2017).

19. Tang, R.C.; Guan, Z.; He, Y.H.; Zhu, W. Enzyme-catalyzed Henry (nitroaldol) reaction. Journal of Molecular Catalysis B: Enzymatic 2010, 63, 62-67, DOI. 10.1016/j.molcatb.2009.12.005 Available online: https://doi.org/10.1016/j.molcatb.2009.12.005 (accessed on accessed on 14 April 2016).

20. Holmberg, E.; Hult, K. Temperature as an enantioselective parameter in enzymatic resolutions of racemic mixtures. Biotechnology letters 1991, 13, 323-326, DOI. 10.1007/BF01027676 Available online: https://doi.org/10.1007/BF01027676 (accessed on accessed on 14 April 2016).

21. Gupta, M.N. Enzyme function in organic solvents. Eur. J. Biochem. 1992, 203, 25-32, DOI. 10.1111/j.1432-1033.1992.tb19823.x Available online: https://doi.org/10.1111/j.1432-1033.1992. tb19823.x (accessed on 23 May 2017).

22. Zaks, A.; Klibanov, A.M. Substrate specificity of enzymes in organic solvents vs. water is reversed. J. AM. Chem. Soc. 1986, 108, 2767-2768, DOI. 10.1021/ja00270a053 Available online: https://doi.org/10.1021/ja00270a053 (accessed on 23 May 2017).

23. Purkarthofer, T.; Gruber, K.; Gruber Khadjawi, M.; Waich, K.; Skranc, W.; Mink, D.; Griengl, H. A Biocatalytic Henry Reaction-The Hydroxynitrile Lyase from Hevea brasiliensis Also Catalyzes Nitroaldol Reactions. Angew. Chem. Int. Ed. Engl. 2006, 45, 3454-3456, DOI. 10.1002/anie.200504230 Available online: https://doi.org/10.1002/anie.200504230 (accessed on 23 May 2017). 